\title{
KONTRIBUSI PEMAHAMAN STRUKTUR KALIMAT IMPLIKASI TERHADAP MATA PELAJARAN MATEMATIKA DI KELAS 2 SLTP
}

\author{
Mohamad Rahmat \\ Dosen Jurusan Pendidikan Matematika FPMIPA \\ rahmat@yahoo.com
}

\begin{abstract}
ABSTRAK
Kevalidan atau kesahihan suatu kesimpulan, Keputusan atau penyelesaian tergantung pada keterkaitan antara fakta-fakta, gejala-gejala, ide-ide (sebagai suatu yang sudah ada, suatu yang diketahui) dengan kesimpulan tersebut. Khususnya dalam bentuk implikasi (1) "jika p, maka q", diubah susunannya atau ditambahkan dengan negasi, menjadi bentuk-bentuk (2) “jika q, maka p" atau (3) "jika bukan p, maka bukan q" atau (4) "jika bukan q, maka bukan p". Jika diketahui nilai kebenaran dari salah satu bentuk itu, dapat diperiksa nilai kebenaran yang lainnya. Pada penelitian ini, penentuan nilai kebenaran dari bentuk (1), (2), (3), dan (4) ini diterapkan pada suatu materi matematika, yaitu persamaan garis di kelas 2 pada 4 SLTPN di Jawa Barat pada catruwulan 2. Pelaksanaan penelitian ini sampel mengikuti langkah sebagai berikut (1) Guru-guru dengan diketahui tim peneliti mengalokasikan waktu untuk materi 'persamaan garis' (12-14 jam pelajaran). (2) Untuk kelas Eksperimen waktu tersebut dikurangi 2 jam pelajaran untuk memberikan kajian implikasi, sedang untuk kontrol waktunya tetap utuh. (3)setelah materi tersampaikan diberikan seperangkat soal berbentuk B-S. (4) Hasil pekerjaan diolah dan dianalisis. Diperoleh hasil sebagai berikut (1) Tanpa melihat bentuk soal B-S, kelas eksperimen memperoleh ratarata 61,7619 dan kelas kontrol memperoleh 57,1871 dengan perbedaan rata-rata 4,5748 dengan skala nilai 0-100 perbedaan ini bermakna dengan taraf kepercayaan $\alpha=0,05$ (2) bilas soal diperhatikan yaitu dengan menggunakan teori peluang, tingkat penguasaan terhadap materi persamaan garis untuk kelas eksperimen 23,5238 dan kelas kontrol 14,3742 dengan skala 0-100 perbedaan ini juga bermakna, karena secara statistik nilai-nilai itu ekuivalen, hanya mentransformasikan dengan menggeser rata-rata dan mengalikan rentang dengan suatu nilai.
\end{abstract}

Kata Kunci: implikasi, bentuk soal, menyimpulkan, menghubungkan

\begin{abstract}
The validity of a conclusion, the decision or completion is depended on relationship between facts, symptom, and ideas (as a thing that had been exist and known) with that conclusion. Especially, "if p, then q", is changed it arrangement or added with negation, become the forms (2) "if q, then p" or (3): "if it is not p, then it is not q" or (4) "if it is not q, then it is not p". It the validity value from one of those forms is known, the other validity was able to be known. On this research, the decision value of this form (1), (2), (3), (4) are applied at a mathematic material, which is the line similarity on second grade at four of State Junior High School (SLTPN) in West Java at second semester. The sample of research followed the steps bellows: (1) knowingly by researcher team, the teachers allocate the time to material "the similarity of line" (12-14 subject hours). (2) for the experimental class, those time is decreased as long 2 hours to give implication teaching, while to it control time is whole (3) after the material or subject was successfully delivered then was given a set of questionnaires in form of B-S. (4) The result of working is processed and analyzed. Meanwhile the results of it are bellows: (1) without looking at the form of $B-S$ questions, the experimental class got average 61, 7619 and control class got 571, 1871 with the difference of average is 4, 5748 with scale value 0-100, the difference means that standard belief $\alpha=0,05$ (2)and if questions is noticed, by using opportunity theory, the power degree to the similarity of line material for the experimental class is 23, 5238 and control class is 14, 3742 with the scale is 0-100 the difference is also means, because statistically those value are equivalent, it is just transform by changing the average and move a distance (in bahasa: rentang) by a value.
\end{abstract}

Keywords: implication, question form, concluding, and connecting.

\section{PENDAHULUAN}

Salah satu tujuan matematika diberikan kepada siswa adalah terbentuknya pemikiran yang logis dan rasional (GBPP-Kurikulum
Dasar, 1993). Berpikir logis adalah adanya keterurutan yang menghubungkan suatu kebenaran (yang benar atau disepakati benar) dengan kebenaran lain yang diuji sehingga 
kebenaran lain itu diyakini benar atau diyakini salah (Solow, 1982). Penghubung bisa berupa pernyataan tunggal atau pernyataan majemuk, pernyataan majemuk banyak berbentuk kalimat implikasi (kondisional) yaitu "jika ..., maka ...". Kalimat implikasi pada mata pelajaran Matematika SLTP sudah mulai digunakan di kelas 1 .

Selain itu soal-soal evaluasi terhadap tujuan pembelajaran umumnya disajikan dalam bentuk kalimat implikasi atau kalimat yang dapat dibentuk menjadi kalimat implikasi.

Berpikir logis dan rasional dapat terbentuk dari nalar deduktif yaitu melalui proses di mana pola penyimpulan diturunkan dari premis secara valid. Untuk menanamkan pemahaman terhadap validitas, dikenalkan melalui nalar kondisional yaitu pola-pola kalimat implikasi berupa modus ponens, modus tollens, sylogisme, invers dan konvers. Bentuk ini dapat diberikan, karena menurut Inhelder dan Piaget usia melewati 12 tahun sudah berada pada tahap berfikir formal ( $\mathrm{G} \mathrm{O}$ Daffer dan A Thornquist, 1993).

Sebagaimana yang diuraikan diatas, masalah dalam penelitian ini adalah: (1) Bagaimana tingkat penguasaan siswa yang diberi perlakuan nalar deduktif implikasi (dengan mengurangi waktu pembahasan materi) terhadap materi matematika; (2) Bagaimana tingkat penguasaan siswa yang tidak diberi perlakuan nalar deduktif implikasi (dengan pembahasan waktu utuh) terhadap materi matematika; dan (3) Apakah penguasaan materi dari siswa yang diberi perlakuan nalar deduktif implikasi lebih baik dari siswa tanpa perlakuan

Masalah di atas dinyatakan penting dengan alasan bahwa pada dasarnya menyimpulkan suatu persoalan baik dalam kehidupan sehari-hari, dan persoalan pada bidang studi, apalagi dalam bidang studi matematika selalu harus mengaitkan gejala-gejala, ide-ide yang telah ada. Suatu kesimpulan merupakan konsekuensi/akibat yang antesedennya kaitan antar gejala-gejala, dan ide-ide.

Seseorang atau siswa dapat menyimpulkan suat persoalan apabila kaitan anteseden dan konsekuensi dipahaminya, artinya harus dipahami apakah kalimat implikasi itu benar atau salah.

Penelitian ini bertujuan untuk melihat sejauh mana peran nalar deduktif berupa pemahaman siswa tentang kalimat implikasi, terhadap penguasaan materi matematika. Untuk tujuan itu, secara garis besar membandingkan tingkat penguasaan materi antara yang diberi perlakuan nalar deduktif melalui kalimat implikasi (dengan mengurangi waktu untuk pembahasan materi) dengan yang tidak diberi pelakuan itu (tetapi dengan waktu pembahasan materi yang utuh).

Penelitian ini diharapkan dapat memberikan kontribusi kepada pengembangan dan pengajaran khususnya kepada: (1) Guru, khususnya guru matematika sebagai pelaksana program pendidikan yang merupakan unsur penting bagi keberhasilan pendidikan dan pengajaran, sehingga mereka mengetahui hasil pekerjaan guna meningkatkan kualitas; (2) Para penyusun dan atau perevisi kurikulum sebagai bahan masukan untuk menyusun dan penyempurnaan kurikulum; dan (3) Para pengguna bahasa, untuk dapat berhati-hati menyimpulkan sesuatu dari suat kalimat implikasi.

Kajian pustaka; Salah satu tujuan matematika diberikan kepada siswa adalah untuk terbentuknya pemikiran yang logis dan rasional (GBPP-Kurikulum Dasar, 1993). Berpikir logis adalah adanya keterurutan yang menghubungkan suat kebenaran (yang benar atau disepakati benar) dengan kebenaran lain yang diuji sehingga kebenaran lain itu diyakini benar atau diyakini salah (Solow, 1982). Kesimpulan mengacu kepada proses di mana satu pernyataan ditegaskan oleh pernyataan yang disepakati (Copi dan Cohen, 1994). 
Menurut penelitian Rahmat (1997), salah satu faktor utama penyebab rendahnya tingkat keterserapan siswa terhadap materi geometri adalah kurang dipahaminya konsep (definisi, aksioma, teorema) matematika oleh sebagian besar siswa. Bentuk definisi, aksioma, dan teorema berupa kalimat-kalimat implikasi, masalah ini beruntun karena cirikhas matematika, jadi sebaiknya jangan terus berjalan manakala ada yang belum dipahami, karena masalah sudah dipecahkan (diselesaikan atau dianggap selesai) akan menjadi aturan untuk masalah berikutnya sebagaimana kata Descartes (Polya, 1981).

Inhelder dan Piaget(G. O'Daffer dan A. Thornquist, 1993) menyatakan bahwa anak pada tahap operasional kongkrit (7-11 tahun) mampu menerima nalar yang umum (bentuk implikasi: Setiap A adalah B, a adalah A, jadi a adalah B), sedang bentuk implikasi lainnya dapat diterima oleh anak yang sudah melewati 12 tahun (tahap operasional formal), umur siswa kelas 2 SLTP umumnya sudah melewati 12 tahun. Jadi, nalar deduktif implikasi bisa diberikan pada siswa kelas 2 SLTP, dengan harapan berpikir logis dan rasional pada dirinya terbentuk.

Kalimat implikasi adalah penggabungan antara dua pernyataan (statements) dengan menempatkan kata "jika" sebelum pernyataan pertama, dan menyisipkan kata "maka" di antara kedua pernyataan itu, pernyataan gabungan itu disebut kalimat bersyarat (conditional), atau kalimat implikasi (implication). Pada implikasi, pernyataan yang mengikuti "jika" disebut anteseden (atau "protasis"), dan pernyataan yang mengikuti "maka" disebut "konsekwen" (atau "apodosis"), kalimat implikasi "jika p, maka q" dilambangkan dengan " $\mathrm{p}=>\mathrm{q}$ " atau " $p \rightarrow q$ " atau " $p \supset q$ ". Nilai kebenaran suat implikasi ditentukan oleh nilai kebenaran anteseden dan nilai kebenaran konsekwen. Nilai kebenaran kalimat implikasi bernilai salah apabila anteseden bernilai sedangkan konsekwennya bernilai salah. Nilai kebenarannya salah apabila susunan nilai kebenaran anteseden dan konsekwennya tidak demikian. Nilai kebenaran itu dapat dilihat pada tabel berikut:

\begin{tabular}{ccc}
\hline$p$ & $q$ & $p \supset q$ \\
\hline$B$ & $B$ & $B$ \\
\hline$B$ & $S$ & $S$ \\
\hline$S$ & $B$ \\
\hline$S$ & $S$ & $B$ \\
\hline
\end{tabular}

Ada empat tipe kalimat implikasi, seperti dicontohkan berikut: (1) Jika semua akan mati dan si Polan adalah manusia, maka si Polan akan mati; (2) Jika ia sarjana, maka ia sudah menikah; (3) Jika kertas lakmus biru ke dalam asam, kertas lakmus itu berubah menjadi merah; dan (4) Jika sekarang hari Kamis, maka $7+7=14$

Pada pernyataan implikasi ke-1, konsekwen timbul sebagai akibat logis dari antesedennya; pada pernyataan ke-2 tidak dapat diketahui apakah konsekwen (sudah menikah) timbul sebagai akibat antesedennya (sarjana); pada pernyataan ke-3 konsekwen timbul sebagai akibat dari antesedennya berdasarkan penemuan empiris, sedangkan pada pernyataan ke-4 konsekwennya tidak dapat diakibatkan oleh antesedennya, walaupun pernyataan implikasinya benar. Tentu saja implikasi yang bermakna, dan dibicarakan dalam penelitian ini adalah implikasi yang konsekwennya merupakan akibat logis (Copi dan Cohen, 1994)

Bila diketahui kalimat implikasi "p $\supset \mathrm{q}$ ", dengan menukar tempat dan atau membubuhkan negasi pada $\mathrm{p}$ dan atau $\mathrm{q}$, akan diperoleh 3 bentuk kalimat implikasi yaitu:

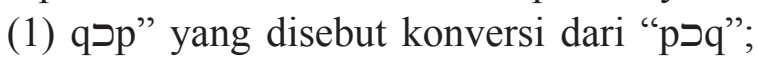
(2) "tidak pつtidakq" yang disebut inversi dari "pכq"; dan (3) "tidak q כtidak p" yang disebut kontra positif dari "pدq" (solow, 1982)

Tentang implikasi ditulis oleh David F. Bjorklund, menyatakan karakteristik operasi mental adalah berpikir formal, salah satunya adalah implikasi yaitu "jika p, maka q". Selanjutnya kemampuan operasi formal 
pada anak digambarkan oleh penelitian Hawkins, Pea, Glick, dan Scriber (1984) yang menampilkan silogisme verbal pada anak 4-5 tahun. Silogisme yang ditampilkan dalam tiga tipe yakni silogisme fantasi, silogisme kongruen, dan silogisme inkongruen, pada silogisme inkongruen hanya $13 \%$ yang menjawab benar. Pada penelitian lain, anak tujuh-tahunan dan orang dewasa banyak yang tidak bisa menyimpulkan implikasi yang invalid, yakni bentuk "Jika ada $P$, maka ada Q. Tidak ada P. Ada Q" (betul/salah?) (Bjorklund, David F., 1989).

Implikasi dengan konversnya memuat masalah yang dapat membuat banyak kekeliruan. Seandainya implikasi "pدq" benar, didapat kalimat implikasi "qつp" yang kebenarannya tidak dapat ditentukan, bisa benar mungkin juga salah, namun banyak orang (demikian pula siswa) keliru dengan menyatakan bahwa implikasi "qวp" juga benar (Copi, 1986).

Dari tulisan di atas suatu implikasi bila susunan dibalik dan atau ditambahi negasi, banyak kekeliruan dalam menyimpulkannya.

\section{METODE PENELITIAN}

Yang menjadi populasi pada penelitian ini adalah seluruh siswa SLTP kelas 2, karena berbagai keterbatasan, dan berbagai pertimbangan diambil sampel penelitian. Sampel penelitian ini terdiri dari 4 SLTP di Jawa Barat, yang masing-masing diambil dua kelas, yakni sebagai kelas eksperimen dan kelas kontrol. SLTP itu yakni SLTPN 7 Bandung, SLTPN 3 Cianjur, SLTPN 2 Karawang, dan SLTPN 2 Purwakarta, dengan rincian sebagai berikut:

\begin{tabular}{|c|c|c|c|c|}
\hline \multirow{2}{*}{ Nama Sekolah } & \multirow{2}{*}{ KelEksp } & \multirow{2}{*}{ Kel Kontrol } & \multicolumn{2}{|c|}{ Banyaknya siswa } \\
\hline & & & $\mathrm{L}$ & $\mathrm{P}$ \\
\hline \multirow{2}{*}{ SLTPN 7 Bandung } & Kelas 2A & & 19 & 25 \\
\hline & & Kelas 2B & 18 & 22 \\
\hline \multirow{2}{*}{ SLTPN 3 Cianjur } & Kelas 2F & & 19 & 18 \\
\hline & & Kelas 2E & 14 & 24 \\
\hline \multirow{2}{*}{ SLTPN 2 Karawang } & Kelas 2E & & 21 & 20 \\
\hline & & Kelas 2F & 18 & 20 \\
\hline \multirow{2}{*}{ SLTPN 2 Purwakarta } & Kelas 2F & & 24 & 22 \\
\hline & & Kelas 2C & 22 & 21 \\
\hline Jumlah & 4 kelas eksp & 4 kelas kontrol & 151 & 172 \\
\hline
\end{tabular}

Instrumen/alat pada penelitian ini terdiri atas: (1) Satuan pelajaran yang berisi materi tentang kalimat implikasi yang dikaitkan dengan materi yang sedang diajarkan, dalam hal ini adalah materi persamaan garis; dan (2) Seperangkat soal-soal untuk mengukur penguasaan tentang materi yang diajarkan sebanyak 25 soal B-S (tentang persamaan garis)

Pelaksanaan penelitian ini melakukan langkah-langkah sebagai berikut: Empat sekolah yang dijadikan sampel, masing-masing menyediakan kelas yang homogenitasnya relatif sama, satu kelas dijadikan kelas eksperimen dan satu kelas dijadikan kelas kontrol; (2) Tim peneliti menyusun satuan pelajaran sisipan, berisi tentang implikasi untuk waktu antara 2 jam pelajaran, hanya untuk kelas eksperimen; (3) Guru-guru pada masing-masing kelas memberikan suat materi (dalam hal ini Persamaan Garis, dengan waktu sekitar 1214 jam pelajaran), dengan menggunakan satuan pelajaran yang mereka buat. Untuk kelas eksperimen, guru diminta menyisipkan materi tentang implikasi tanpa tambahan waktu, sedang untuk kelas kontrol tanpa diberi sisipan tentang implikasi; (4) Tim peneliti membuat soal tentang materi persamaan garis, soal diberikan kepada kelas kontrol maupun kelas eksperimen; dan (5) Pekerjaan siswa pada 4 dianalisis. 
Pada penelitian ini terdapat perlakuan dengan nalar deduktif implikasi dan adanya kelas kontrol, untuk itu, perlu dinyatakan hipotesis penelitian.

Hipotesis nol: Tidak terdapat perbedaan rata-rata nilai antara kelas yang mendapat pengajaran nalar deduktif implikasi dengan rata-rata kelas yang mendapat pengajaran nalar deduktif implikasi.

Hipotesis alternatif: Rata-rata nilai kelas yang mendapat pengajaran nalar deduktif implikasi lebih besar dari rata-rata nilai kelas yang tidak mendapat pengajaran nalar deduktif implikasi/

$\mathrm{H}_{0}: \mu_{1}=\mu_{2} \quad \mathrm{H}_{0}: \mu_{1}>\mu_{2}$

Tingkat kebermaknaan : $\alpha=0,05$

Uji statistic

$$
\begin{aligned}
& \mathrm{z}_{\text {hitung }}=\frac{\bar{J}_{1}-\bar{J}_{2}-\left(\mu_{1}-\mu_{2}\right)}{\sqrt{\frac{\sigma_{1}^{2}}{n_{1}}+\frac{\sigma_{2}^{2}}{n_{2}}}} \\
& \mathrm{H}_{0} \text { ditolak jika } \mathrm{z}_{\text {hitung }} \geq \mathrm{z}_{\text {tabel }(\alpha)}
\end{aligned}
$$

\section{Pengolahan dan Analisis Data}

Pengolahan dan analisis data untuk penelitian ini menggunakan program komputer SPSS

\section{Deskripsi Hasil Penelitian}

1. Sampel berdasarkan jenis kelamin

\begin{tabular}{lcc}
\hline Jenis Kelamin & Banyaknya & Persentasi \\
\hline Laki-laki & 151 & 46,7 \\
\hline Perempuan & 172 & 53,3 \\
\hline Jumlah & 323 & 100,0 \\
\hline
\end{tabular}

2. Distribusi sampel tiap sekolah

\begin{tabular}{lcc}
\hline Nama Sekolah & Frekuensi & Persentasi \\
\hline SLTPN 7 Bandung & 82 & 25,4 \\
\hline SLTPN 3 Cianjur & 73 & 22,6 \\
\hline SLTPN 2 Karawang & 79 & 24,5 \\
\hline SLTPN 2 Purwakarta & 89 & 27,6 \\
\hline Jumlah & 323 & 100,0 \\
\hline
\end{tabular}

3. Sampel berdasarkan kelas eksperimen dengan kontrol

\begin{tabular}{lcc}
\hline Kelas & Banyaknya & Persentasi \\
\hline Eksperimen & 168 & 52,0 \\
\hline Kontrol & 155 & 48,0 \\
\hline Jumlah & 323 & 100,0 \\
\hline
\end{tabular}

4. Distribusi frekuensi nilai

\begin{tabular}{ccc}
\hline Nilai & Freq & Persentase \\
\hline 24,00 & 1 &, 3 \\
\hline 32,00 & 3 &, 9 \\
\hline 36,00 & 4 & 1,2 \\
\hline 40,00 & 9 & 2,8 \\
\hline 44,00 & 21 & 6,5 \\
\hline 48,00 & 27 & 8,4 \\
\hline 52,00 & 39 & 12,1 \\
\hline 56,00 & 40 & 12,4 \\
\hline 60,00 & 48 & 14,9 \\
\hline 64,00 & 41 & 12,7 \\
\hline 68,00 & 34 & 10,5 \\
\hline 72,00 & 27 & 8,4 \\
\hline 76,00 & 7 & 2,2 \\
\hline 80,00 & 12 & 3,7 \\
\hline 84,00 & 4 & 1,2 \\
\hline 88,00 & 3 &, 9 \\
\hline 92,00 & 3 &, 9 \\
\hline jumlah & 323 & 100,0 \\
\hline
\end{tabular}

\section{Ukuran Statistik}

Mean/rata-rata: 59,567; median: 60,000; modus: 60,000; Simpangan baku: 11,547; Minimum: 24,00; Maximum: 92,00; Jumlah Nilai: 19240,000

\section{Pengolahan Data}

Berikut hasil pengolahan uji-t untuk kelas eksperimen dengan kelas kontrol:

\section{Feb 00 SPSS for MS Windows Release 6.00}

Dari pengolahan komputer didapat nilai perbedaan rata-rata sebesar 4,5748. Dengan perbedaan sebesar itu perlu diperiksa apakah perbedaannya bermakna. Dari pengolahan komputer didapat $t_{\text {hitung }}=3,62$. Bila nilai $\mathrm{t}_{\text {hitung }}$ ini dibandingkan dengan nilai $\mathrm{t}_{\text {tabel }}=1,645$ maka diperoleh $t_{\text {tabel }}<t_{\text {hitung. }}$ Sebagaimana terlihat dalam gambar. 


\section{Mean Difference $=4.5748$}

Leven's Test for Equality of Variances : $F=.586 \mathrm{P}=445$

\begin{tabular}{cccccc}
\hline \multicolumn{4}{c}{ t-test for Equality of Means } & & $95 \%$ \\
\hline Variances & t-value & df & 2-Tail Sig & SE of Diff & CI of Diff \\
\hline Equal & 3.62 & 321 & .000 & 1.262 & $(2.091,7.059)$ \\
\hline Unequal & 3.64 & 320.94 & .000 & 1.258 & $(2.100,7.050)$ \\
\hline
\end{tabular}

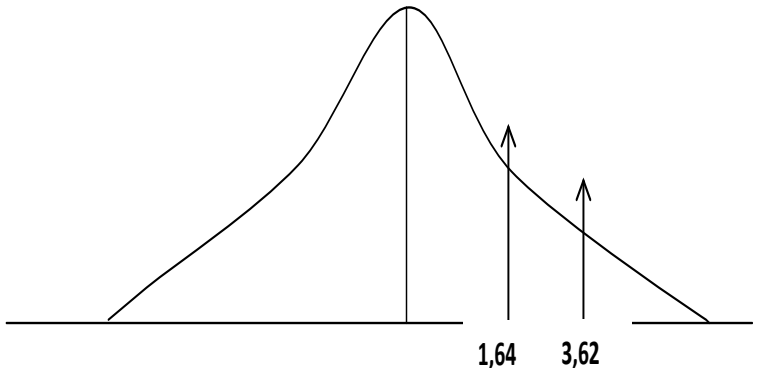

Jadi sesuai dengan kriteria pengujian haruslah hipotesis nol ditolak. Artinya perbedaan rata-rata antara nilai perolehan pada kelas eksperimen dan kelas kontrol berbeda.

Kesimpulannya nilai penguasaan materi dari siswa yang diberi perlakuan nalar deduktif implikasi lebih baik dari siswa tanpa perlakuan nalar deduktif implikasi.

Namun, bila soal yang berbentuk B-S (betulsalah) diperhatikan (dikerjakan secara acak yaitu dikerjakan oleh orang-orang tanpa pengetahuan yang diteskan), maka kecenderungan rata-ratanya sekitar $50 \%$. Jika kita perhatikan nilai rata-ratanya kelas eksperimen sebesar 61,7619 dan kelas kontrol 57,1871 sedangkan rata-rata gabungannya 59,567, maka tingkat penguasaan dari materi masing-masing kelas adalah sebagai berikut: (1) Untuk kelas eksperimen sebesar 61,7619$38,2381=23,5238$; (2) Untuk kelas kontrol sebesar 57,1871-42,2129=14,9742; dan (3) Untuk kelas gabungan sebesar 59,567$40,433=19,134$

Angka-angka tersebut sangat jauh dari harapan.

\section{KESIMPULAN}

Dari hasil pengolahan dan analisis data diatas, dapat disimpulkan sebagai berikut:
1. Tingkat penguasaan siswa yang tidak diberi perlakuan nalar deduktif implikasi (dengan waktu pembahasan utuh) terhadap materi matematika, yang dalam hal ini materi persamaan garis sangat kecil yaitu 14,9742. Namun, bila nilai itu tidak memperhitungkan 'untung-untungan' dalam memilih mencapai 57,1871.

2. Tingkat penguasaan siswa yang diberi perlakuan nalar deduktif implikasi (dengan waktu pembahasan utuh) terhadap materi matematika, yang dalam hal ini materi persamaan garis, yaitu 23,5238. Namun bila nilai itu tidak memperhitungkan 'untung-untungan' dalam memilih mencapai 61,7619 .

3. Penguasaan materi dari siswa yang diberi perlakuan nalar deduktif implikasi lebih baik secara bermakna dari siswa tanpa perlakuan nalar deduktif implikasi, dengan perbedaan rata-rata sebesar 4,5748. mengingatkan bagaimana memahami kalimat implikasi.

4. Penilaian dengan memperhatikan bentuk soal (yang selama ini nampaknya tidak dilakukan) akan berakibat makin kecilnya nilai penguasaan matematika. 


\section{DAFTAR PUSTAKA}

Bjorklund, D. F. (1989), Children's Thinking, Developmental Function and Individual Difference. Brocks/Cole Publishing Company Pacific Grove, California

Copi, I. M. dan Cohen, C. (1994), Introduction to Logic, Ninth Edition, MacMillan Publishing Company, New York

Davis, R. H; Alexander, L. T dan Yelon, S. L. (1974), Learning System Design, An Approach to The Improvement Of Instruction, McGraw-Hill Book Company, New York

Departemen Pendidikandan Kebudayaan (1993), Kurikulum Pendidikan Dasar, Garis-garis Besar Program Pengajaran SLTP, Mata Pelajaran Matematika, Jakarta

Dolan, D. T., Williamson, J. (1983), Teaching Problem-Solving Strategies, Addison-Wesley Publishing Company, Menlo Park, California

Dowdy, S. dan Wearden, S. (1991). Statistic Research, Second Edition, John Willey\&Sons, New York.

Emmet, E. R., (1980), Learning to Think, Emerson Books, Inc, Buchanan, New York

Galloway, C. (1976), Psychology For Learning and Teaching, McGraw-Hill, Book Company

G. O’Daffer, Pharesdan A. Thornquist, Bruce, Critical Thinking, Mathematical Reasoning, and Proof, dalam S. Wilson, Patricia (1993), Research Ideas For The Classroom, National Council of Teachers of Mathematics, Macmillan Publishing clCompany, New York.

Goodstein, L. D; Nolan, T. M. dan Pfeiffer, J. W. (1993), Applied Strategic Planning, A Comprehensive Guide, McGraw-Hill, Inc, New York.

Polya, G. (1981), Mathematical Discovery, On Understanding, learning, and Teaching Problem Solving, John Willey\&Sons, New York

Rahmat, M. (1997), Keterserapan Materi Geometri oleh Siswa SLTP kelas 2 Caturwulan 1 di Kotamadya Bandung, LaporanPenelitian, Fakultas Pendidikan Matematikadan Ilmu Pengetahuan Alam, Instituk Keguruandan Ilmu Pendidikan, Bandung

Solow, D. (1981), How To Read and Do Proof, An Introduction to Mathematical Thougt Process, John Willey \& sons, New York

Soedjadi, R dan Moesono, Dj. (1995), Matematika untuk SLTP (1a s.d. 2a), Departemen Pendidikandan Kebudayaan, BalaiPustak, Jakarta.

Stoll, R. R. (1976), Set Theory and Logic, Eurasia Publishing House (PVT) Ltd. Ram Nagar, New Delhi-110055 